\title{
Genus revisions and new combinations of some North European polypores
}

\author{
TUOMO NIEMELÄ, JUHA KINNUNEN, KARL-HENRIK LARSSON, DMITRY S. SCHIGEL \\ and ELLEN LARSSON
}

\begin{abstract}
Niemelä, T., Kinnunen, J., Larsson, K.H., Schigel, D.S. \& Larsson, E. 2005: Genus revisions and new combinations of some North European polypores. - Karstenia 45: 75-80. ISSN 0453-3402.

Two new genera of polypores (Basidiomycota) are described, Erastia Niemelä \& Kinnunen, and Rhodonia Niemelä \& K.H. Larsson. The following new combinations are presented: Antrodiella canadensis (Overh.) Niemelä, Erastia salmonicolor (Berk. \& M.A. Curtis) Niemelä \& Kinnunen, Oligoporus balsaminus (Niemelä \& Y.C. Dai) Niemelä, Oligoporus immitis (Peck) Niemelä, Oligoporus persicinus (Niemelä \& Y.C. Dai) Niemelä, Porodaedalea laricis (Jacz. ex Pilát) Niemelä, and Rhodonia placenta (Fr.) Niemelä, K.H. Larsson \& Schigel. Porodaedalea niemelaei M. Fischer is considered to be synonymous with P. laricis, and Sarcoporia polyspora P. Karst. was found to be an older name for the species commonly known as Parmastomyces transmutans (Overh.) Ryvarden \& Gilb. or P. mollissimus (Maire) Pouzar.
\end{abstract}

Key words: Basidiomycota, Antrodiella, Erastia, Parmastomyces, Phellinus, Porodaedalea, Rhodonia, Sarcoporia, polypore, taxonomy

Tuomo Niemelä, Juha Kinnunen and Dmitry S. Schigel, Botanical Museum, Finnish Museum of Natural History, P.O. Box 7, FI-00014 University of Helsinki, Finland

Karl-Henrik Larsson and Ellen Larsson, Botanical Institute, Göteborg University, P.O. Box 461, SE-40530 Göteborg, Sweden

\section{Introduction}

In this paper two genera are described and new combinations are made in order to make these names available for a forthcoming book on Finnish polypores (Niemelä 2005).

\section{Materials and methods}

The authors' names of this paper are abbreviated as TN, JK, KHL, DSS and EL, respectively.

Some of the results derive from our literature and herbarium studies, but a considerable part has accumulated during the preparation of a phylogenetic analysis of the generic complex Postia/Oligoporus. In that study KHL and EL sequenced and analyzed a large set of species and specimens mostly provided by TN, JK and DSS. That extensive phylogenetic revision will be fully presented and discussed in another, forthcoming paper.

\section{Taxonomy}

Antrodiella canadensis (Overh.) Niemelä, comb. nova

[Polyporus canadensis Overh., Mycologia 33:97, 1941, nomen inval.]

Basionym: Polyporus canadensis Overh. in Lowe, Mycotaxon 2:45, 1975. - Holotype: 'Polyporus canadensis sp. nov., Ottawa, Dow's Swamp, on spruce stump, 16.IX.1933 J.W. Groves 16860' (PAC, studied).

There has been some controversy on the validity of the description of this species. Ryvarden and Gilbertson (1984) considered that in the article in Mycotaxon 2:44-45 Lowe described the species twice in different genera (Polyporus, Tyromyces), which would be against the Code, and 
hence a nomen novum Antrodiella overholtsii Ryvarden \& Gilb. was created. Niemelä (1985) accepted the publication of Polyporus canadensis as valid and legitimate, because Overholts was explicitly given as its author and Overholts' description was separated into a footnote apart from Lowe's running text.

After reconsidering the case TN came to the conclusion that the validating description in Lowe (1975) is an authentic, posthumously printed text by Overholts with original wording, and should be accepted as such. This accords with the interpretation in Index of Fungi 5(9): 360, 1985 (“L. O. Overholts apud Lowe"). A discussion on this matter with Dr. Teuvo Ahti (Helsinki) is gratefully acknowledged.

Niemelä (1985) kept this species in the heterogeneous genus Tyromyces. Johannesson et al. (2000) compared it and several Antrodiella species with ribosomal DNA sequences, and showed that they make a natural, monophyletic clade, thus supporting the idea of Ryvarden and Gilbertson (1984) that this is a member of Antrodiella. Hence the new combination is made here; TN thanks P. Renvall (Kuopio, Finland), the second author of the Johannesson et al. (2000) paper, for discussions concerning Antrodiella and this species.

\section{Erastia Niemelä \& Kinnunen, genus novum}

Carpophorus annuus, effusus, poroideus, succulentus, salmonicolor. Systema hypharum monomiticum, hyphae tenuitunicatae, fibulatae. Sporae ellipsoideae.

Type: Polyporus salmonicolor Berk. \& M.A. Curtis.

Etymology: Dedicated to Prof. Erast Parmasto (Tartu, Estonia), the eminent researcher of fungal taxonomy and cladistics.

Basidiocarp annual, effused, poroid, soft juicy, pale salmon coloured, when dry discoloured but not turning dark purple-red in bruised parts or elsewhere. $\mathrm{KOH}$ reaction almost nil at pore surface, or light cherry red in ochraceous-coloured mycelium of basidiocarp margins and subiculum. Hyphal system monomitic, hyphae thin-walled, with clamp connections, weakly amyloid in tube trama, acyanophilous. Brown oily matter abun- dant in between the hyphae. Spores thin-walled, ellipsoid, negative in both Melzer's reagent and Cotton Blue, ca. 4-5.7 $\times 2.5-2.9 \mu \mathrm{m}$ in type species, with one prominent oil-guttule.

\section{Erastia salmonicolor (Berk. \& M.A. Curtis) Niemelä \& Kinnunen, comb. nova}

Basionym: Polyporus salmonicolor Berk. \& M.A. Curtis, Hooker's J. Bot. Kew Gard. Misc. 1:104, 1849. Type: 'Pol. salmonicolor Berk. \& Curt. 1527, [U.S.A., South Carolina, Berkely Co.,] Santee River, H.W. Ravenel' (K, studied by Ryvarden 1977).

This species was illustrated in colour in Bernicchia (2005:665, at least the upper photograph), and it and Hapalopilus aurantiacus will be illustrated by Niemelä (2005). These two species, and $H$. ochraceolateritius Bondartsev, have been misunderstood in most modern papers. Pouzar (1967) analysed the protologues of aurantiacus and salmonicolor and concluded that they cannot mean the same species. Donk (1967) discussed the identities and typifications of these names, without giving any clear answer.

In our opinion Hapalopilus aurantiacus, $H$. ochraceolateritius and Erastia salmonicolor are three well-defined species. The best differentiating characters are listed in Table 1. At least in North Europe the first one is the commonest, the others extremely rare. They all grow on coniferous trees.

Ko et al. (2001) studied phylogenetic relationships among the Hapalopilus complex. They found that 'Hapalopilus' salmonicolor is in fact alien to the genus, while $H$. rutilans and $H$. croceus are closely related. They proposed salmonicolor to be included in the genus Sarcoporia, as was already done by Teixeira (1986). Below we will show that this is unacceptable, and hence the new genus Erastia was described.

Hapalopilus ochraceolateritius was first described by Karsten (1887) as Physisporus aurantiacus var. saloisensis P. Karst. That name was never validly transferred to species rank, and Bondartsev (1940) eventually described it as a species. Domański (1965) was one of the few who adopted Bondartsev's idea and clearly knew the species. 
Table 1. Comparison of Erastia salmonicolor, Hapalopilus aurantiacus and H. ochraceolateritius.

\begin{tabular}{|c|c|c|c|}
\hline Character & E. salmonicolor & H. aurantiacus & H. ochraceolateritius \\
\hline Pores per mm & $1-2$ & $(1-) 2-3$ & $(3-) 4-6$ \\
\hline Fresh colour & salmon or pinkish & $\begin{array}{l}\text { orange-yellow or } \\
\text { ochraceous }\end{array}$ & brick or terracotta \\
\hline Dry colour & dirty pale brownish & $\begin{array}{l}\text { dark ochraceous, or } \\
\text { purple reddish }\end{array}$ & $\begin{array}{l}\text { dark brick, or black with } \\
\text { blood-red tint }\end{array}$ \\
\hline Bruised parts (dry) & almost unchanged & reddish black & reddish black \\
\hline $\mathrm{KOH}$ & $\begin{array}{l}\text { almost unchanged, or } \\
\text { light cherry red in } \\
\text { subiculum and margin }\end{array}$ & dark blood red & dark blood red \\
\hline Spore shape & ellipsoid & thick cylindric & narrow cylindric \\
\hline Spore size (average) & $\begin{array}{l}4-4.7 \times 2.5-2.9 \mu \mathrm{m} \\
\mathrm{L}=4.3 \mu \mathrm{m}, \mathrm{W}=2.7 \mu \mathrm{m} \\
\mathrm{Q}=1.6\end{array}$ & $\begin{array}{l}4.9-6 \times 2.2-2.6 \mu \mathrm{m} \\
\mathrm{L}=5.4 \mu \mathrm{m}, \mathrm{W}=2.4 \mu \mathrm{m} \\
\mathrm{Q}=2.2\end{array}$ & $\begin{array}{l}4.3-5.2 \times 1.8-2.1 \mu \mathrm{m} \\
\mathrm{L}=4.7 \mu \mathrm{m}, \mathrm{W}=2.0 \mu \mathrm{m} \\
\mathrm{Q}=2.4\end{array}$ \\
\hline Host in N Europe & pine & pine or spruce & pine or spruce \\
\hline
\end{tabular}

\section{Sarcoporia polyspora $\mathrm{P}$. Karst.}

Another misinterpretation was found while studying Karsten's type materials addressed to the Hapalopilus / Erastia complex. Lowe (1956) considered the type of Sarcoporia polyspora P. Karst. to be conspecific with Physisporus aurantiacus var. saloisensis P. Karst., i.e. what is here called Hapalopilus ochraceolateritius. That view has been followed ever since. The holotype of Sarcoporia polyspora is deposited in Herb. H (Helsinki); although small and blackened, the specimen is good for microscopy. Hyphal structure is monomitic, with clamps and plenty of oily droplets in between the hyphae. The specimen is abundantly fertile (polyspora!), spores being slightly thick-walled, ellipsoid with obtuse ends, dextrinoid and very strongly cyanophilous, (4.5-)4.6-6.1(-6.5) × (2.6-)2.7-3.3(-3.4) $\mu \mathrm{m}$, $\mathrm{L}=5.34 \mu \mathrm{m}, \mathrm{W}=2.99 \mu \mathrm{m}, \mathrm{Q}=1.79(\mathrm{n}=30 / 1)$. It is certainly the same species as what is nowadays known as Parmastomyces transmutans (Overh.) Ryvarden \& Gilb. (holotype Overholts 22971, PAC, studied) or P. mollissimus (Maire) Pouzar, and much older than these two names. As this is the type of both the genus and the species, the widely used epithets under Parmastomyces must be abandoned. The genus name Sarcoporia fits very well for the species, because the basidiocarp attains flesh-reddish tints in the course of its growth and if bruised. The specimens are always very rich in spores.

Oligoporus balsaminus (Niemelä \& Y.C. Dai) Niemelä, comb. nova

Basionym: Postia balsamina Niemelä \& Y.C. Dai, Karstenia 44:68, 2004. Holotype: Finland, Kittilän Lappi, Kolari, Picea abies, 31.VIII.1999 Niemelä 6601 \& Dai $(\mathrm{H})$.

Phylogenetic analysis carried out by KHL and EL from Finnish materials of the Postial Oligoporus complex and related genera revealed the heterogeneous nature of this group. Preliminary results show that thick-spored species make up a clade around Oligoporus rennyi (Berk. \& Broome) Donk, type of Oligoporus. Most of the narrow-spored species are closely related to Pos- 
tia lactea (Fr.) P. Karst., type of the genus Postia. For this reason this combination was made, as well as the two below.

Oligoporus balsaminus is a northerly species, growing on spruce in old-growth forests. In the microscope it resembles O. balsameus (Peck) Gilb. \& Ryvarden, but spores of $O$. balsaminus are slightly larger, basidiocarps are predominantly effused, with larger pores and gelatinous subiculum. During drying the specimens of $O$. balsaminus shrink and become brittle, while $O$. balsameus becomes hard or chalky and keeps its shape fairly well.

\section{Oligoporus immitis (Peck) Niemelä, comb. nova}

Basionym: Polyporus immitis Peck, New York State Mus. Nat. Hist. 35:135, 1884.

While studying O. stipticus (Pers. : Fr.) Gilb. \& Ryvarden and O. guttulatus (Peck) Gilb. \& Ryvarden, still another species was detected in this group of fungi. The main differences are shown in Table 2. According to the proposal of
W. Spirin (St.Petersburg, Russia), this name was accepted for the taxon; usually it is listed as one of the many synonyms of O. stipticus. Another possible name would be Tyromyces tiliophilus Murrill (Murrill 1907, cf. Ryvarden 1985:196), and further studies are needed to solve the taxonomy and nomenclature of this taxon.

Oligoporus persicinus (Niemelä \& Y.C. Dai) Niemelä, comb. nova

Basionym: Postia persicina Niemelä \& Y.C. Dai, Karstenia 44:74, 2004. Holotype: Finland, Kittilän Lappi, Kolari, Picea abies, 17.VIII.1999 Niemelä 6453 \& Dai $(\mathrm{H})$.

Porodaedalea laricis (Jacz. ex Pilát) Niemelä, comb. nova

[Xanthochrous pini (Brot.) Pat. subsp. abietis (P. Karst.) Bourdot \& Galzin var. laricis Jacz. ex Pilát, Bull. Trimestriel Soc. Mycol. France 48:28, 1933 ('1932'), nomen nudum.]

Table 2. Comparison of Oligoporus stipticus, O. guttulatus and O. immitis.

\begin{tabular}{|c|c|c|c|}
\hline Character & O. stipticus & O. guttulatus & O. immitis \\
\hline Pores per mm & $4-5(-6)$ & $5-6(-7)$ & $4-5$ \\
\hline Upper surface fresh/dry & white/citric yellow & $\begin{array}{l}\text { cream }+ \text { tan zones/ } \\
\text { ochraceous yellow }\end{array}$ & $\begin{array}{l}\text { white/white with tan } \\
\text { flecks }\end{array}$ \\
\hline Pore surface fresh/dry & white/citric yellow & $\begin{array}{l}\text { greenish white/yellowish or } \\
\text { greyish cream }\end{array}$ & $\begin{array}{l}\text { white/dark brownish } \\
\text { cream }\end{array}$ \\
\hline Dry context \& tubes & hard & soft chalky & soft chalky \\
\hline Taste & bitter, peppery & sour & sour \\
\hline Context hyphae & $\begin{array}{l}\text { both the straight } \\
\text { 'conductive', and } \\
\text { interwoven narrow } \\
\text { hyphae thick-walled }\end{array}$ & $\begin{array}{l}\text { straight 'conductive' hyphae } \\
\text { thick-walled, interwoven and } \\
\text { narrow hyphae thin-walled }\end{array}$ & $\begin{array}{l}\text { straight 'conductive' hyphae } \\
\text { thick-walled, interwoven } \\
\text { and narrow hyphae thin- } \\
\text { walled }\end{array}$ \\
\hline Spores (average) & $\begin{array}{l}4-5.1 \times 1.9-2.4 \mu \mathrm{m} \\
\mathrm{L}=4.5 \mu \mathrm{m}, \mathrm{W}=2.1 \mu \mathrm{m}, \\
\mathrm{Q}=2.0-2.2\end{array}$ & $\begin{array}{l}3.5-4.9 \times 2.2-2.6 \mu \mathrm{m} \\
\mathrm{L}=4.1 \mu \mathrm{m}, \mathrm{W}=2.4 \mu \mathrm{m} \\
\mathrm{Q}=1.7-1.8\end{array}$ & $\begin{array}{l}3.9-4.5 \times 1.9-2.1 \mu \mathrm{m}, \\
\mathrm{L}=4.1 \mu \mathrm{m}, \mathrm{W}=2.0 \mu \mathrm{m} \\
\mathrm{Q}=2.1\end{array}$ \\
\hline Host in N Europe & $\begin{array}{l}\text { coniferous trees } \\
\text { (mostly Picea) }\end{array}$ & $\begin{array}{l}\text { coniferous trees } \\
\text { (mostly Picea) }\end{array}$ & $\begin{array}{l}\text { deciduous trees (Betula, } \\
\text { Quercus, Juglans etc.) }\end{array}$ \\
\hline
\end{tabular}


Basionym: Xanthochrous pini (Brot.) Pat. f. laricis Jacz. ex Pilát, Bull. Trimestriel Soc. Mycol. France 49:272, 1934 ('1933'). Holotype (the only specimen listed): "Ad truncos Laricis sibiricae in Sibiria, districtus Tara, 1.IX.1928, leg. Murashkinsky" (not studied).

Phellinus laricis (Jacz. ex Pilát) Pilát, Bull. Trimestriel Soc. Mycol. France 88:346, 1972.

Pilát described $\mathrm{f}$. laricis from material forwarded to him by A.A. Jaczewski, but the latter clearly was not a coauthor ("Jaczewski pro spec. in litt."). So it is appropriate to address the taxon to Jacz. ex Pilát, or just Pilát. The description is valid, even though the name is not listed in recent indexes of fungal names. Dai (2005) seems to be the only modern author who interpreted it correctly.

While making the new combination Phellinus laricis, Pilát (1972) addressed the description of f. laricis to page 273, while the correct page is 272. This is a technical error and does not make the combination invalid; in fact the description of the new form (Pilát 1934) still continues on that page. Donk (1974:329) did not present any reservations on its validity. In the same paper Pilát (1972) indicates a more recent collection from Mongolia (PRM 712454) as 'neotypus', without explaining the reason. The wording implies that the original material was lost, but that was not checked for this paper.

Phellinus laricis is clearly a member of the 'Phellinus pini complex'. Molecular studies (Fischer 1996, Wagner \& Fischer 2001, 2002) have shown that the old genus Phellinus is too heterogeneous to be kept undivided, and Porodaedalea is the name for the more natural genus. This species was recently described as Porodaedalea niemelaei $\mathrm{M}$. Fischer from material collected on Larix sibirica in Finland (Fischer 2000). Larch is not indigenous to the country, and it is clear that the strictly host-specific fungus originates from the range of Larix sibirica, i.e. northeastern parts of European Russia and Siberia. In fact $P$. laricis is common from the Veps forest (eastern Leningrad Region; the westernmost natural site of Larix sibirica) up to China (Y.C. Dai, H. Kotiranta and others, pers. comm.).

\section{Rhodonia Niemelä \& K.H. Larsson, genus novum}

Carpophorus annuus, effusus, poroideus, mollis, roseicolor vel niveus. Systema hypharum monomiticum, hyphae fibulatae, primo tenuitunicatae, in statu maturo crassitunicatae. Sporae cylindricae.

Type: Polyporus placenta Fr.

Etymology: Rhodonia (fem.), from rhodon, Greek name of rose, referring to the pale pink colour reminiscent of that in wild roses.

Basidiocarp annual, effused, poroid, fairly thick, juicy and soft, pale rose-coloured or white. Hyphal system monomitic, hyphae with clamp connections, at first thin-walled but in mature basidiocarp thick-walled. Spores cylindric. Causing a brown rot on coniferous trees.

\section{Rhodonia placenta (Fr.) Niemelä, K.H. Larsson} \& Schigel, comb. nova

Basionym: Polyporus placenta Fr., Öfvers. Kungl. Vetensk.-Akad. Förh.: 30, 1861.

The strongest evidence for separating $R$. placenta from Oligoporus and Postia comes from molecular analysis, where this becomes invariably nested far off from those genera, in a separate clade near Antrodia (our results). This will be illustrated and discussed thoroughly in a forthcoming paper. Young basidiocarps have consistently thin-walled hyphae, but when they grow older, some hyphae become thick-walled, and then the structure looks like dimitic. Most hyphae of fully grown basidiocarps are thick-walled to subsolid.

This species has been well described in many papers, e.g. Ryvarden and Gilbertson (1994) and Bernicchia (2005). The gradual thickening of hyphal walls has been mostly neglected, however. A good hint for identification is seen in Cotton Blue / lactic acid mounts: small greasy droplets are dispersed in the mountant, and in 1-2 minutes they become fragmented and 'explode' into snowflake-like groups. Such fenomenon is not seen in Antrodia infirma or other similar-looking species.

It is not yet known which other species are related. Both externally and in the microscope Antrodia infirma Renvall \& Niemelä is very similar, but this relationship needs to be studied more closely. A possible candidate would also be Oligoporus mappa (Overh. \& J. Lowe) Gilb. 
\& Ryvarden. - The species names placenta and mappa are nouns, and stay uninflected irrespective of the gender of the genus.

Acknowledgements: Reima Saarenoksa (Helsinki) and Wjacheslav Spirin (St. Petersburg) are thanked for notes and collections of Oligoporus immitis. Pertti Renvall (Kuopio) shed light in the phylogeny of Antrodiella canadensis. The identities and distributions of $O$. balsaminus and $O$. persicinus were discussed with Heikki Kotiranta (Helsinki). Teuvo Ahti (Helsinki) helped in finding names for the new genera; he also revised the Latin descriptions and helped TN in deciding the validity of the name Polyporus canadensis. The Ministry of Environment is thanked for a generous research grant (YM175/5512/2004), which enabled TN and DSS to carry out studies in mycology.

\section{References}

Bernicchia, A. 2005: Fungi Europaei 10. Polyporaceae s.1. - Edizioni Candusso, Alassio. 808 pp.

Bondartsev, M.A. 1940: O novykh gribakh sem. Polyporaceae. - Bot. Mater. Otd. Spor. Rast. Bot. Inst. Akad. Nauk SSSR 5: 17-23. [In Russian]

Dai, Y.C. 2005: Illustrations of pathogenic wood-decaying fungi in China. - Science Press, Beijing. 197 pp. [In Chinese]

Domański, S. 1965: Grzyby (Fungi), podstawczaki bezblaszkowe, zagwiowate 1, szczecinkowate 1. Państwowe Wydawnictwo Naukowe, Warszawa. 280 pp. + 63 pls.

Donk, M.A. 1967: Notes on European polypores 2. Notes on Poria. - Persoonia 5: 47-130.

Donk, M.A. 1974: Check list of European polypores. - Verh. Koninkl. Nederlandse Akad. Wetensch. Afd. Natuurk. Tweede Reeks 62: 1-469.

Fischer, M. 1996: Molecular and microscopical studies in the Phellinus pini group. - Mycologia 88: 230-238.

Fischer, M. 2000: Porodaedalea (Phellinus pini group, Basidiomycetes) in Europe, a new species on Larix sibirica, P. niemelaei. - Karstenia 40: 43-48.

Johannesson, H., Renvall, P. \& Stenlid, J. 2000: Taxonomy of Antrodiella inferred from morphological and molecular data. - Mycol. Res. 104: 92-99.
Karsten, P.A. 1887: Fungi novi vel minus bene cogniti Fenniae et Galliae descripsit. - Rev. Mycol. 9: 9-11.

Ko, K.S., Jung, H.S. \& Ryvarden, L. 2001: Phylogenetic relationships of Hapalopilus and related genera inferred from mitochondrial small subunit ribosomal DNA sequences. - Mycologia 93: 270-276.

Lowe, J.L. 1956: Type studies of the polypores described by Karsten. - Mycologia 48: 99-125.

Lowe, J.L. 1975: Polyporaceae of North America. The genus Tyromyces. - Mycotaxon 2: 1-82.

Murrill, L.O. 1907: Polyporaceae. - North American Flora 9: 1-131.

Niemelä, T. 1985: On Fennoscandian polypores 9. Gelatoporia n. gen. and Tyromyces canadensis, plus notes on Skeletocutis and Antrodia. - Karstenia 25: 21-40.

Niemelä, T. 2005: Käävät, puiden sienet. Polypores, lignicolous fungi. - Norrlinia 13: 1-320. [In Finnish, with English summary]

Pilát, A. 1934: Additamenta ad floram Sibiriae Asiaeque orientalis mycologicam. Pars secunda. - Bull. Trimestriel Soc. Mycol. France 49: 256-339.

Pilát, A. 1972: Contribution a l'étude des basidiomycètes de la Mongolie. - Bull. Trimestriel Soc. Mycol. France 88: 333-356 + plates.

Pouzar, Z. 1967: Studies in the taxonomy of the polypores 3. - Česká Mykologie 21: 205-212.

Ryvarden, L. 1985: Type studies in the Polyporaceae 17. Species described by W.A. Murrill. - Mycotaxon 23: 169-198.

Ryvarden, L. \& Gilbertson, R.L. 1984: Type studies in the Polyporaceae 15. Species described by L.O. Overholts, either alone or with J.L. Lowe. - Mycotaxon 19: $137-144$.

Ryvarden, L. \& Gilbertson, R.L. 1994: European polypores 2. Meripilus to Tyromyces. - Synopsis Fungorum 7: 389-743.

Teixeira, R. 1986: New names and new combinations in the Polyporaceae. - Revista Brasil. Bot. 9: 43-44.

Wagner, T. \& Fischer, M. 2001: Natural groups and a revised system for the European poroid Hymenochaetales (Basidiomycota) supported by nLSU rDNA sequence data. - Mycol. Res. 105: 773-782.

Wagner, T. \& Fischer, M. 2002: Proceedings towards a natural classification of the worldwide taxa Phellinus s.l. and Inonotus s.1., and phylogenetic relationships of allied genera. - Mycologia 94: 998-1016. 